\title{
Considering a Lexicographic Plan for Gabon within the Gabonese Language Landscape*
}

\author{
Hugues Steve Ndinga-Koumba-Binza, Stellenbosch University Centre for \\ Language and Speech Technology (SU-CLaST), Stellenbosch, Republic of \\ South Africa(13751719@sun.ac.za / h_steve75@yahoo.fr)
}

\begin{abstract}
This article raises a number of questions that should be dealt with in drawing up a lexicographic plan for Gabon. For which of the Gabonese languages should lexicographic units be established? This question entrains the issue of inventorying the Gabonese languages and their standardization as well as the issue of language planning for Gabon. What is the status of those foreign languages widely spoken in Gabon? What about French? Should Gabon keep importing its French dictionaries from France, or should the Gabonese compile their own French dictionaries, including French words and expressions exclusively used in Gabon? Finally, after trying to answer these questions, a number of suggestions are made for the establishment of a lexicographic plan for Gabon.
\end{abstract}

Keywords: GABONESE LANGUAGE LANDSCAPE (GLL), LEXICOGRAPHIC PLAN FOR GABON, LANGUAGE DIVERSITY, LANGUAGE POLICY, LANGUAGE STANDARDIZATION, GABONESE LEXICOGRAPHY, NATIONAL LANGUAGE, NATIVE LANGUAGES, FOREIGN LANGUAGES

Opsomming: Die oorweging van 'n leksikografiese plan vir Gaboen binne die Gaboenese taallandskap. Hierdie artikel bring 'n aantal vrae ter sprake waaraan aandag gegee moet word by die opstel van 'n leksikografiese plan vir Gaboen. Vir watter Gaboenese tale moet leksikografiese eenhede gestig word? Hierdie vraag bring die kwessie van die inventarisering van die Gaboenese tale en hul standaardisering ter sprake, asook die kwessie van taalbeplanning vir Gaboen. Wat is die status van daardie vreemde tale wat algemeen in Gaboen gepraat word? Wat van Frans? Moet Gaboen voortgaan om sy Franse woordeboeke uit Frankryk in te voer, of moet hy sy eie Franse woordeboeke saamstel, met insluiting van Franse woorde en uitdrukkings wat uitsluitlik in Gaboen gebruik word? Ten slotte, nadat geprobeer is om hierdie vrae te beantwoord, word 'n aantal voorstelle gemaak vir die totstandbrenging van 'n leksikografiese plan vir Gaboen.

Sleutelwoorde: GABOENESE TAALLANDSKAP (GTL), LEKSIKOGRAFIESE PLAN VIR GABOEN, TAALVERSKEIDENHEID, TAALBELEID, TAALSTANDAARDISERING, GABOENESE LEKSIKOGRAFIE, LANDSTAAL, INHEEMSE TALE, VREEMDE TALE

* An earlier version of this article was presented as a paper at the Ninth International Conference of the African Association for Lexicography hosted by the Groupe de Recherche en Langues et Cultures Orales (GRELACO) and held at the Omar Bongo University in Libreville, Gabon, 21-23 July 2004. 


\section{Introduction}

The aim of this article is to raise some questions Gabonese lexicographers might consider while drawing up a strategic plan for Gabonese lexicography. These questions are discussed within the Gabonese language landscape (henceforth GLL, a term coined by Ndinga-Koumba-Binza 2003). However, in order to set the framework for this article, the GLL as well as the current lexicographic plan of Gabon (henceforth LPG) are outlined before considering issues in drawing up the LPG.

\section{The Gabonese language landscape}

\subsection{The concept}

A view or a picture of the countryside is referred to as a landscape. The term language landscape may be defined as an accurate picture of the languages, both foreign and native, used in a given geographical area (Ndinga-Koumba-Binza 2003). This concept applies to both multilingual countries and countries with language diversity, Gabon belonging to the latter group.

The concept of a language landscape can be wider than that of a language situation. Indeed, there are some differences between the two. The language (or linguistic) situation is viewed in terms of the native languages in a given country. Authors such as Jacquot (1978), Perrois, Jacquot and Moussavou (1983), Kwenzi-Mikala (1990), Mba-Nkoghe (1991), Blanchon (1994), Raponda-Walker (1998), Emejulu and Nzang-Bié (1999), Nyangone Assam and Mavoungou (2000), and Mavoungou (2002a), among others, have outlined the language situation in Gabon. A review of these studies shows that the linguistic situation in Gabon is described by highlighting the following four points (Mavoungou 2002a):

(a) a mere acknowledgement of Gabon as a country with language diversity instead of a multilingual country,

(b) a description of the particular status of French in Gabon,

(c) an inventory and classification of the native languages, and

(d) a brief description of the status of the native languages.

The term linguistic situation seems to be reserved for referring to the native languages; therefore the term language landscape is proposed for referring to the comprehensive linguistic countryside. When considering the language landscape, both native and foreign languages in the language diversity of the country are taken into account. Finally, the GLL reflects an on-field reality that can be broadly represented by the following figure: 


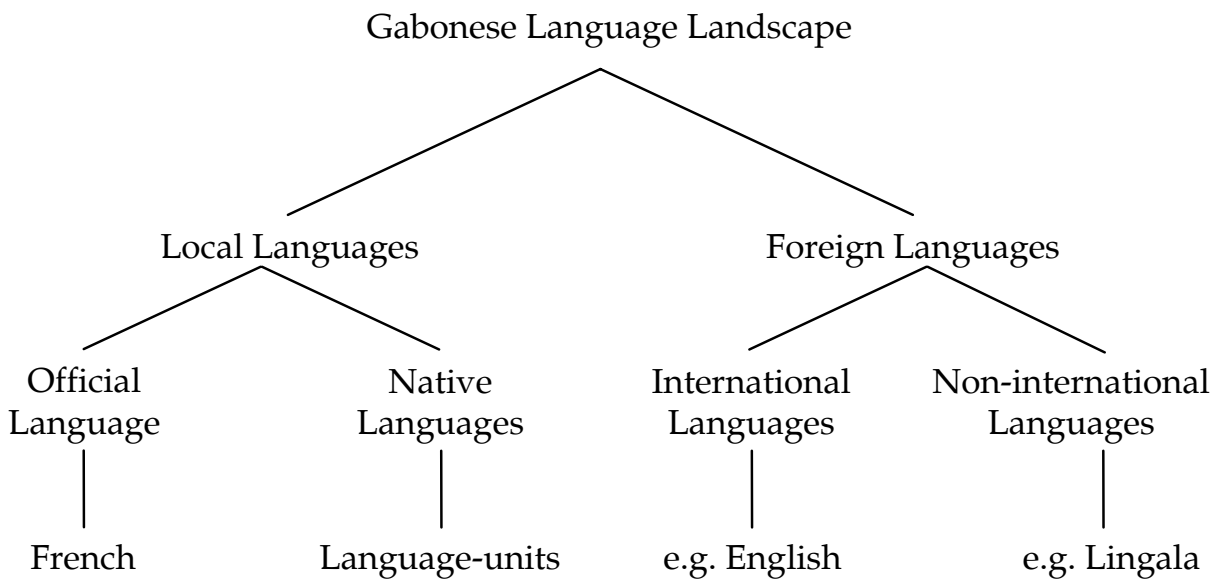

The GLL considers both local and foreign languages spoken in Gabon, since the linguistic countryside of Gabon comprises both local languages and foreign languages, as shown by the above tree diagram (taken from Ndinga-KoumbaBinza 2003 and forthcoming).

Local languages, which include native languages and the official language, refer to languages identified in accordance with a certain place through cultural inheritance (about the native languages, see Emejulu 2000 and 2003 for further details on the Gabonese heritage languages) and/or through linguistic policy (about the official language, see Mavoungou 2002b, Pambou 1998 and NdingaKoumba-Binza forthcoming for details on French as a Gabonese language according to the Constitution, and see Moussirou Mouyama 1984 and 1986 for details on French as a Gabonese language by reason of colonization). French has ceased being a foreign language in Gabon (Pambou 1998, Ndinga-KoumbaBinza forthcoming) since it is the only official language of the country, and the only language used in all official and public sectors (administration, business, education, media, etc.).

Foreign languages refer to languages not the mother tongues of the indigenous population of Gabon (see Addenda 2, 3 and 4), including the mother tongues of the migrant populations. Often these languages are excluded from the Gabonese language census (Blanchon 1994, Idiata 2002).

\subsection{Native languages}

The most recent work on making an inventory of the Gabonese native languages is that of Kwenzi-Mikala (1987, 1988, 1990 and 1998). According to his classification (see Addendum 1), he identifies 62 speech patterns (parlers) in Gabon that he groups into 10 language-units (unités-langues) on the basis of the 
sociological criterion of starting a conversation with the formula "I say that" as well as the criterion of mutual intelligibility. Kwenzi-Mikala (1988: 57 and 1990: 122) states that a language-unit is a group or a set of different mutually comprehensible speech forms.

Many writers (Blanchon 1994, Emejulu and Nzang-Bié 1999, Nyangone Assam and Mavoungou 2000, Emejulu 2000, Idiata 2002 and Ndinga-KoumbaBinza forthcoming) have criticized the grouping of Gabonese languages into language-units on various aspects, mainly for being referred to as a classification and for lacking a suitable measurement for mutual intelligibility. However, in this article, Kwenzi-Mikala's grouping is viewed from the perspective of a language inventory. In fact, despite the criticism levelled at it, this inventory might sufficiently contribute to "a solution to the problem of the enumeration of all the heritage speech forms of Gabon" (Nyangone Assam and Mavoungou 2000: 254). Furthermore, it can be assumed that by using the terms language-units and speech patterns Kwenzi-Mikala tried to avoid the terms languages and dialects, which are very controversial in the Gabonese context at both political and linguistic levels. Thus, on the basis of historical dialectological criteria, it can be argued that Kwenzi-Mikala's ten language-units might be ten specific native languages found in Gabon. This is true within a historical dialectological approach seeking the standardization of these non-standardized Gabonese languages or speech forms. In other respects, many of the smaller speech forms are near extinction due to the very small number of their speakers.

\subsection{Foreign languages}

As far as Gabon is concerned, foreign languages are frequently spoken, since in a population of 1379000 inhabitants (Crystal 1999: 130), 15,2\% are foreigners (according to a 2003 estimation). The fact that migrant communities speak their own languages, which in Gabon sometimes have more speakers than some native languages, should be reflected in the language census of the country.

In Ndinga-Koumba-Binza (2003 and forthcoming) the language immigration in Gabon is described as well as the settlement and spreading of the foreign languages throughout Gabon. However, apart from the sociolinguistic survey conducted between 1998 and 1999 by the Laboratoire des Sciences Humaines et de la Dynamique du Language (LASCIDYL) (Tomba Moussavou 2001), no systematic inventory of the foreign languages spoken in Gabon has ever been undertaken. Meanwhile, Tomba Moussavou (2001: 13) who is responsible for the survey of LASCIDYL, puts the figure at 49 African languages used on a daily basis in Libreville, the capital city of Gabon.

She also mentions six European languages (including French), one language from the Middle East (Arabic) and one unidentified Creole language. The latter seems to be one of the three forms of Creole found in São Tomé and Príncipe. Ndinga-Koumba-Binza (2003 and forthcoming) believes that field- 
workers of LASCIDYL did not ascertain from their Creole-speaking informants the form of Creole they claimed to speak, nor did they pay attention to Asian languages, such as Japanese, Chinese and Korean, and to languages from Eastern and Southern Africa.

From both the Ethnologue records (Grimes 1996) and the work of LASCIDYL, and from on-field observations, Ndinga-Koumba-Binza (2003 and forthcoming) has established a wider list of foreign languages spoken in Gabon (see Addenda 2, 3 and 4).

The GLL as outlined above should be taken into account in both the language planning and lexicographic plan for Gabon.

\section{An embryonic lexicographic plan for Gabon}

A lexicographic plan for Gabon (LPG) is still in its embryonic stage. By an LPG should be understood what Emejulu (2003: 205) refers to as "the strategic planning of Gabonese lexicography". Currently, Gabonese lexicography (Nyangone Assam and Mavoungou 2000; Emejulu 2001a, 2002b and 2003) is at five simultaneous phases in its development:

(a) lexicographic training,

(b) metalexicographical accounting for dictionaries,

(c) circumscribing lexicography as a career,

(d) formulating a coherent general framework for Gabonese lexicography, and

(e) updating reference works inherited from missionaries and colonial administrators.

Although only recently established, Gabonese metalexicography experiences a fast-growing crop of literature. This is the consequence of an extensive number of Gabonese lexicographers being trained at the University of Stellenbosch. In fact, "the strategic planning of Gabonese lexicography gives the highest priority to training," as Emejulu (2003: 205) stresses.

At this stage, eight Gabonese students are undergoing doctoral training in lexicography and two have completed their doctorates in lexicography at the University of Stellenbosch (see Emejulu 2003: 205-207 and Gouws 2001 for further information on the training of future Gabonese lexicographers).

The two newly graduated doctors in lexicography have joined the staff of the Groupe de Recherche en Langues et Cultures Orales (GRELACO) at the Omar Bongo University, Libreville. In fact, in accordance with the terms of its mission, GRELACO conducts research in the field of lexicography and metalexicography headed by J.D. Emejulu and Y. Nzang-Bié, two Gabonese linguists specializing in lexicography (see Emejulu 2000 and Nzang-Bié 2002). 
Thus, lexicography is becoming a career at university level as it draws scholars into basic lexicographic research. As part of Gabonese lexicography, a number of Gabonese lexicographers at present focus on the planning of dictionaries (Mavoungou 2002a, Nzang-Bié 2002, Afane Otsaga 2004) and the improvement of the quality of existing dictionaries (Nyangone Assam and Mavoungou 2000, Mihindou 2001, Mabika Mbokou 2004) within a metalexicographical framework.

Emejulu (2000, 2001a, 2002a and 2003) has proficiently defined lexicography as an opportune career in Gabon and formulated a coherent general framework for Gabonese lexicography. Mavoungou (2001a) has also contributed in this sphere by describing the inception of dictionary production in Gabon and presenting the challenges of globalization with special reference to dictionary-making in Gabon.

In general, the LPG is intended to be an economic asset in the development of Gabon (Emejulu 2000, 2003). Emejulu (2000: 65) says:

For an immediate answer, in pure economic and commercial terms, lexicography is and should be treated as an economic and commercial variable that is governed essentially by market laws. It is, at least, job-creating in all its areas of execution and oriented to generate money. The development of such a realistic lexicography in Gabon will rely primarily on the strict adherence to basic economic and market principles both in its planning and execution.

Moreover, Emejulu (2003: 196) adds, "the remedial strategy for lexicography is to go beyond the higher institutions and reach out to broader society to unleash its full potential as an effective factor in development". Finally, the LPG is intended to develop in a general framework of the "dynamics for a viable and profit-making lexicography in a fast-changing, multilingual global melting pot", as Emejulu (2003: 197) puts it.

The organization of the Ninth International Conference of the African Association for Lexicography (AFRILEX) by GRELACO in Libreville, Gabon (July 2004), manifested a will-power for establishing lexicography in Gabon and for conceiving a specific lexicographic plan for this country.

Apart from the training of lexicographers and consistent publication-orientated research, GRELACO has equipped itself with reliable and modern technology and has signed a co-operation agreement with the Bureau of the Woordeboek van die Afrikaanse Taal (WAT) in Stellenbosch, Republic of South Africa (Emejulu 2003: 208). This agreement has allowed GRELACO researchers to receive practical computer-oriented training "in the various fields of production and marketing of dictionaries, data processing and management of lexicographic units, and strategic planning" at the Bureau of the WAT (Emejulu 2003: 205). The Bureau of the WAT has also agreed to assist GRELACO in the process of establishing lexicographic units across Gabon to cater for the need of recognized Gabonese languages (Emejulu 2003: 208). This agreement with the Bureau of the WAT is part of the GRELACO policy of co-operative lexicography (see Emejulu 2003: 207-209 for further information on this policy). 
At present, it can be concluded that GRELACO has paved the way for a viable LPG, which is still to be elaborated.

No decision has yet been taken at government level with regard to dictionary-making for the Gabonese languages or the use of lexicographic techniques and models for the development of the Gabonese languages. Lexicography in Gabon is still confined to GRELACO and its research projects (most of them not sponsored by the government).

As for lexicographic practice, i.e. the practical component of lexicography (Gouws 2001: 59), two eras of dictionary production in Gabonese lexicography can be distinguished:

(a) The earlier era, which includes reference works from missionaries and colonial administrators. Nyangone Assam and Mavoungou (2000), Mihindou (2001) and Mavoungou (2001b) have showed that the majority of lexicographic reference works available in the Gabonese languages are bilingual dictionaries, lexicons and glossaries compiled by Catholic and Protestant missionaries and colonial administrators from 1800 to 1960, when Gabon gained its independence from France.

(b) The modern era, which starts from 2002 with the publication of Gedandedi sa Geviya/Dictionnaire Geviya-Français (henceforth DGF) by Van der Veen and Bodinga-bwa-Bodinga. Mavoungou (2004: 440) points out that the appearance of this dictionary opens a new era of dictionary publication in Gabon. The DGF was followed in 2004 by the Lexique Pove-Français/Français-Pove by Mickala Manfoumbi. This period coincides with the completion of the first theses on metalexicographical planning of dictionaries in the Gabonese languages (Mavoungou 2002a and Afane Otsaga 2004).

These two eras have this in common that dictionary production took place outside a general framework or strategic planning. None of these dictionaries was compiled on the basis of a theoretical conception, i.e. a metalexicographical design. In fact, in all countries lexicographic practice has the tendency to develop and become established in a pre-theoretical environment. This is why Gouws (2001: 59) can state: "Lexicographic practice is older than metalexicography."

The lack of a metalexicographical grounding for dictionary production in Gabon has caused that serious issues in the development of Gabonese languages have been overlooked, as will be seen in the following section. At the same time, the newly established Gabonese metalexicography has failed in effecting a concrete well-designed strategic planning, i.e. a LPG (cf. the five simultaneous phases in the development of Gabonese lexicography).

The following section deals with issues to be considered in drawing up an LPG. These include challenges in Gabonese linguistics, the status of the French language and the consideration of foreign languages. The question is how Gabonese lexicography will deal with these issues. 


\section{Issues regarding the LPG}

\subsection{Challenges in Gabonese linguistics}

Since the establishment of the Department of Language Sciences at Omar Bongo University in 1994, it has become clear that Gabonese linguistics faces a number of challenges. Though Gabonese linguistics might be said to have started with the work of Catholic and Protestant missionaries and colonial administrators, the majority of Gabonese languages are still undeveloped. According to Alberts (2004: xiv), "a language complies with the common definition of standardization if there are grammars, spellings and orthography rules, dictionaries and terminology available in that language". This definition might be suitable for a standard language which can be extended to a developed or modernized language.

Language standardization, development and/or modernization are not the only challenges for Gabonese linguistics. A study of the trends in Gabonese linguistics might show numerous linguistic issues with which the LPG will have to deal. Only a few will be mentioned, especially those that might be seen as important in the process of drawing up a language policy and/or language plan for Gabon.

\subsubsection{A language policy and language plan for Gabon}

The current language policy appears to be a continuation of the colonial language policy that ruled the use of French as the only official language (KwenziMikala 1990). Thus, even given the will of the government to promote the native Gabonese languages (see Nzang-Bié 2001 and Dodo-Bounguenza 2002), there is a great need for a new language policy. Ndinga-Koumba-Binza (forthcoming) argues that setting a proper language policy in place is a necessity for the development of the Gabonese languages.

The language policy should take into account the GLL and should include the whole process of language development, from fundamental research to school textbooks and dictionary compilation. Issues such as the number of languages, language standardization and the introduction of native languages into the education system should be dealt with within the framework of a language policy. ${ }^{1}$

The current language policy of Gabon is merely stated in one paragraph of the Constitution: "The Republic of Gabon adopts French as the offical language. Furthermore, she endeavours to protect and promote national languages" (Art. 2 , par. 8). This one-paragraph statement constitutes the sole constitutional provision with regard to languages. It stipulates French to serve as "the sole medium of instruction in the national educational system, and as the language of business, in civil administration and the media" (Nyangone Assam and Mavoungou 2000: 255). 


\subsubsection{The native languages in Gabon}

The number of native languages in Gabon has been an issue in numerous publications, and, as yet, there has not been any proposition that brings unanimity (see Kwenzi-Mikala 1987, Emejulu and Nzang-Bié 1999, Emejulu 2003, Idiata 2002 and 2003 for more information on this issue). The exact number of Gabonese native languages is still not known. According to Blanchon (1994: 1341), "due to important variation from one village to another and sometimes even between one individual to another, the exact number of languages or dialects is hard to determine".

However, the main reason for the uncertainty about the exact number of languages lies in the differentiation between languages and dialects. In fact, many dialects are regarded as different languages, and some languages, because of their limited number of speakers, are often seen as dialects of some other more extensive neighbouring languages. Ndinga-Koumba-Binza (forthcoming) points out that grouping both languages and dialects into various language-units without trying to distinguish between them (as Kwenzi-Mikala did), seems to be a way of resolving the issue.

An LPG may have to deal with this issue when answering the question for which of these languages lexicographic units should be established.

\subsubsection{Language standardization}

There is no standard language among the Gabonese native languages. The term standard language is here used in the sense of a form or a variety of any given language "which is learned and accepted as correct across a community or set of communities in which others are also used" (Matthews 1997: 352). Indeed, the 62 speech patterns distinguished by Kwenzi-Mikala are dialects and variants of various languages whose number will hardly reach ten, when the language-units of Kwenzi-Mikala are recognized.

Given the fact that "dictionaries reflect the characteristic way in which a language has become standardized in a given situation" (Gallardo 1980: 61), an LPG will also have to deal with the issue of language standardization when the question is considered for which languages lexicographic units should be established. It will be necessary to differentiate a standard variety of the language from other dialects. Therefore, an investigation will be needed to establish which process would be suitable for language standardization. In this matter, Kwenzi-Mikala's internal classification of language-units seems to be an important help. However, Afane Otsaga (2004) has recently argued that a standard translation dictionary, the first of its kind in Gabonese lexicography, might be used as an instrument for standardizing the Fang language. Earlier, Mavoungou (2002a) had suggested that the compilation of a trilingual Yilumbu-English-French dictionary might eventually contribute to the standardization of the Yilumbu language. 
The standardization process of Gabonese languages will not only be "the choice and acceptance of the standard dialect by the speech community", but also "the choice and use of a unique spelling system for the reading and writing of these languages" (Afane Otsaga 2004: 218).

\subsubsection{Writing system}

The Gabonese native languages are still called non-written languages. However, most of these languages inherited considerable literatures from missionaries and colonial administrators. In fact, missionaries and colonial administrators established writing systems, alphabets, orthographies and spellings for the Gabonese native languages. These writing systems, alphabets, orthographies and spellings were mainly copies of their mother tongues, i.e. French, English and Portuguese.

Recently a number of proposals have been made for writing the Gabonese languages (see Idiata (2002 and 2003) and Hubert and Mavoungou (forthcoming) for further details). However, about the Gabonese orthographic alphabet adopted at a workshop in April 1999, unanimity has still not been reached, not only among linguists, but also between linguists and language practitioners and teachers. The orthographic alphabet, like many other Gabonese linguistic products, is still waiting for governmental approval and adoption for prospective national diffusion and implementation.

The role of an LPG will be to bring about, through dictionary production, the unanimity that is still lacking and to initiate the implementation of the proposed alphabet. The implementation of the proposed alphabet will provide a platform for the development of writing systems and a unique spelling system for the Gabonese languages.

\subsection{The French language in Gabon}

What about French in Gabon? Should Gabon keep importing its French dictionaries from France, or should the Gabonese compile their own French dictionaries, including French words and expressions exclusively used in Gabon? This implies that French should first be taken into account within an LPG. Mavoungou (2002b) has recently conceived a metalexicographical plan for a monolingual dictionary of the French language as spoken in Gabon. The first draft of this dictionary has been completed and the dictionary is ready for publication. ${ }^{2}$

The compilation of the dictionary entitled Dictionnaire $d u$ Français $d u$ Gabon (DFG) presents a view that considers French as one of the Gabonese languages. This view falls within the framework of the GLL. French, the only official language, being the language most often spoken and used, is definitely a Gabonese language, not only for being given the status of the only official language, but also for being the mother tongue of the younger generations in Gabon (Blanchon 1994, Pambou 1998, Moulougi Nguimbyt 2002). 
Taking this view into account, an LPG should also have the following aims:

- The production of all types of monolingual French dictionaries (LSP, learner's, school dictionaries, etc.) as in other French-speaking countries where the local French has been standardized (cf. Belgian French, Cameroonian French, Canadian French, Haitian French, Malian French, Senegalese French, etc.

- The production of bilingual French dictionaries with other European languages as target languages (preferably languages taught in school, i.e. English, Spanish and German). Gabonese French can also serve as target language, other European languages being source languages of planned bilingual dictionaries.

The DFG seems to be only a repertoire of particular items in the French language as spoken in Gabon. These Gabonisms, usually designating specific extralinguistic Gabonese realities (not in the French culture) are mostly items derived from native Gabonese languages (see Mavoungou 2002b for further details), e.g. Ndjobi (a secret society), nyembwe (sauce from palm nuts), nkoumou (meal from leaves of the Gnetum africanum).

Other items include, in addition to place names, also loan shifts, loan blends and formations based on native-language roots (this list of types of Gabonisms is not exhaustive).

However, the French language as it is spoken in Gabon does not only refer to Gabonisms (for details on the French language in Gabon, see Couvert 1982, Moulougui Nguimbyt 2002, Moussirou Mouyama 1984 and 1986, Ndinga-Koumba-Binza 2004, Ogden 1984, Pambou 1998 and Tomba Moussavou 2001). Therefore, the DFG should consider Gabonese French not only in its general core level, i.e. standard French, but also official French (acrolectal level), common French (mesolectal level) and popular French (basilectal level). All four levels are present in the French language as it is spoken in Gabon (see Mavoungou 2002b and Moulougui Nguimbyt 2002 for details).

Currently planned dictionaries (for instance Mavoungou 2002a and Afane Otsaga 2004) and a number of existing dictionaries have French as source or target language. This is the case with dictionaries such as Galley (1964), Van der Veen and Bodinga-bwa-Bodinga (2002) and Mikala Manfoumbi (2004). The Dictionnaire Français-Mpongwé (Raponda-Walker 19952), the Dictionnaire Français-Vili (Marichelle 1902) and the Dictionnaire Français-Ndumu et Ndumu-Français (Biton 1907) could also, among others, be mentioned.

All these dictionaries view French as a foreign language. The LPG should consider French as one of the Gabonese languages.

\subsection{Criteria and the nationality criterion}

The LPG as currently designed focuses directly on the so-called Gabonese lan- 
guages, i.e. the native Gabonese languages. However, Ndinga-Koumba-Binza (forthcoming) points out that these languages can hardly be called Gabonese languages since there is no official documentation from the state or government giving them such an identification.

In fact, as mentioned earlier, the Constitution of the Republic of Gabon only states the adoption of French as official language of the country (Art. 2, par. 8) and assigns the government to make efforts in protecting and promoting the national languages. The Constitution has to be questioned because none of the so-called national languages are mentioned in it. Moreover, there has not been any further governmental arrangements in favour of the native languages. Therefore, there is no stipulation differentiating the native languages from foreign languages. They are all just languages spoken in Gabon.

Many native languages could hardly be claimed to be Gabonese languages, since they could also be Cameroonian, Equatorial Guinean and/or Congolese languages, seeing that they are also spoken in these countries. This is true of languages such as Fang (also used in Equatorial Guinea and São Tomé and Príncipe, cf. Grimes 1996), Civili (spoken along the Atlantic Ocean coast from the southern province of Gabon to the northern province of Angola), Yipunu (spoken in Gabon, in the Republic of the Congo and in the Democratic Republic of the Congo), Yinzebi (also spoken in the Republic of the Congo), and Teke (also used in the Republic of the Congo and the Democratic Republic of the Congo).

Trends in current Gabonese lexicography show a definite focus on native languages on the basis of nationality without attention being paid to languages also used in other (surrounding) countries, though these foreign languages are spoken more in Gabon (according to the number of speakers) than some of the native languages. This is the case with Eveia compared to Yoruba, Igbo and Hausa (all three Nigerian languages).

In their recently published dictionary, Van der Veen and Bodinga-bwaBodinga (2003) mention in the pretexts that Eveia is a language with fewer than 50 speakers. The compilers even point out that the language is only spoken in one single village partly landlocked in the centre of the country. Such a language can obviously not contribute to a money-generating lexicography. In fact, the Eveia-speaking population has a very small impact on the Gabonese economy compared to Nigerian immigrants of whom the majority live in the capital Libreville and have an extensive influence on the national economy through their businesses (it is acknowledged that the Kalaba population has a certain control of the fishing industry at Pont Nomba and on the market of that area of Libreville). More issues are at stake than mere monetary gains in lexicography which anywhere is not known for big profits. The focus here on the monetary aspect is due to "the strategic planning for Gabonese lexicography" which intends to make lexicography an economic asset for Gabon (Emejulu 2000 and 2003).

The question to the planners of Gabonese lexicography is: Should the LPG prefer Eveia and ignore the language of the Kalaba population? If rigorous cri- 
teria for selecting a language for the development of a Gabonese economically strategic lexicography have to be established, many native Gabonese languages will be disqualified due to their number of speakers, their impact on the national economy and their advance towards extinction. This is the case with Eveia.

On the contrary, language development is usually more sensitive to national than economic goals (Harris and Rampton 2003).

\section{Conclusion}

This article has tried to raise a number of issues that planners of Gabonese lexicography may have to deal with. Possible directions to follow are indicated for each issue. For instance, lexicographic units should be established according to Kwenzi-Mikala's classification of Gabonese into certain language-units. This implies the issue of inventorying the Gabonese languages and the issue of their standardization as well as the issue of a language plan for Gabon.

The article also advocates the consideration of certain foreign languages widely spoken in Gabon, especially French accepted as sole official language of the country. A specific form of French that includes exclusively Gabonese words and expressions should result from Gabonese dictionary production.

Finally, the article discusses the concept of the Gabonese language landscape (GLL) which acknowledges both native and foreign languages for a better understanding and presentation of a realistic linguistic plan for Gabon.

\section{Notes}

1. Ndinga-Koumba-Binza (forthcoming) gives more details on the Gabonese language policy and number of suggestions for establishing a new language policy for Gabon.

2. L. Mabika Mbokou, T. Afane Otsaga, G.-R. Mihindou and B. Nyangone Assam are among Gabonese lexicographers involved in this project of the Dictionnaire du Français du Gabon.

\section{References}

\section{Dictionaries}

Biton, A. 1907. Dictionnaire français-ndumu et ndumu-français, précédé d'éléments de grammaire. Nantes: Imprimerie Bourgeois.

Galley, Samuel. 1964. Dictionnaire fang-français/français-fang. Neuchatel: Henri Messeiller. Marichelle, C. 1902. Dictionnaire français-vili. Loango: Imprimerie de la Mission.

Mikala Manfoumbi, Roger. 2004. Lexique pove-français français-pove. Libreville: Éditions RapondaWalker.

Raponda-Walker, A. 19952. Dictionnaire français-mpongwé. Libreville: Éditions Raponda-Walker.

Van der Veen, Lolke J. and Sébastien Bodinga-bwa-Bodinga. 2002. Gedandedi sa Geviya/Dictionnaire geviya-français. Louvain/Paris/Sterling, Virginia: Peeters. 


\section{Other Literature}

Afane Otsaga, Thierry. 2004. The Standard Translation Dictionary as an Instrument in the Standardization of Fang. Unpublished D.Litt. Dissertation. Stellenbosch: University of Stellenbosch.

Alberts, Mariëtta. 2004. A Few Words from AFRILEX. Lexikos 14: xiv-xv.

Blanchon, Jean A. 1994. Gabon: Language Situation. Asher, R.E. (Ed.). 1994. The Encyclopedia of Language and Linguistics. Volume 3. Oxford/New York: Pergamon Press.

Couvert, C. 1982. Langue française en République gabonaise. Paris: Haut Comité de la Langue Française.

Crystal, David. 1999. The Penguin Dictionary of Language. Second Edition. Harmondsworth: Penguin Books.

Dodo-Bounguenza, E. 2002. Les langues du Gabon: le point en 2001. Le Gabon et l'Unesco, Revue d'information 2: 33-39.

Emejulu, James D. 2000. Lexicography, an Economic Asset in Multilingual Gabon. Revue Gabonaise des Sciences du Langage/Gabonese Journal of Language Sciences 1: 51-69.

Emejulu, James D. 2001a. Lexicographie multilingue et multisectorielle au Gabon: planification, stratégie et enjeux. Emejulu, J.D. (Ed.). 2001: 38-57.

Emejulu, James D. (Ed.). 2001b. Éléments de lexicographie gabonaise. Tome 1. New York: Jimacs-Hillman Publishers.

Emejulu, James D. 2002a. Défis et promesses de la lexicographie intégrale dans les pays en développement. Emejulu, J.D. (Ed.). 2002: 366-381.

Emejulu, James D. (Ed.). 2002b. Éléments de lexicographie gabonaise. Tome 2. New York: Jimacs-Hillman Publishers.

Emejulu, James D. 2003. Challenges and Promises of a Comprehensive Lexicography in the Developing World: The Case of Gabon. Botha W.F. (Ed.). 2003. ' $n$ Man wat beur. Huldingingsbundel vir Dirk van Schalkwyk: 195-212. Stellenbosch: Bureau of the WAT.

Emejulu, James D. and Yolande Nzang-Bié. 1999. Linguistic Perspectives in Gabon. Unpublished paper presented at the International Meeting of the Summer Institute of Linguistics, University of North Dakota, July 1999.

Gallardo, A. 1980. Dictionaries and the Standardization Process. Zgusta, L. (Ed.). 1980. Theory and Method in Lexicography: 59-69. Columbia: Hornbeam Press.

Gouws, Rufus H. 2001. Lexicographic Training: Approaches and Topics/Formation lexicographique: approches et thèmes. Emejulu, J.D. (Ed.). 2001: 58-94.

Grimes, Barbara (Ed.). 1996. Ethnologue. Thirteenth Edition. Dallas: Summer Institute of Linguistics, Inc.

Harris, Roxy and Ben Rampton (Eds.). 2003. The Language, Ethnicity and Race Reader. London/New York: Routledge.

Hubert, Jacques and Paul A. Mavoungou. (Eds.). Forthcoming. Écriture et Standardisation des Langues Gabonaises. Submitted for publication to The Centre for Advanced Studies in African Society (CASAS) in Cape Town.

Idiata, Daniel F. 2002. Il était une fois les langues du Gabon. Libreville: Éditions Raponda-Walker.

Idiata, Daniel F. 2003. Pourquoi le Gabon doit investir sur ses langues vernaculaires. Cape Town: The Center for Advanced Studies of African Society (CASAS).

Jacquot, André. 1978. Le Gabon. Barreteau, D. (Ed.). 1978. Inventaire des études linguistiques sur les langues d'Afrique noire d'expression française et sur Madagascar. Paris: CILF. 
Kwenzi-Mikala, Jerôme T. 1987. Contribution à l'inventaire des parlers bantu du Gabon. Pholia 2: 103-110.

Kwenzi-Mikala, Jerôme T. 1988. L'identification des unités-langues bantu gabonaises et leur classification interne. Muntu 8: 54-64.

Kwenzi-Mikala, Jerôme T. 1990. Quel avenir pour les langues gabonaises? Revue Gabonaise des Sciences de l'Homme 2: 121-124.

Kwenzi-Mikala, Jerôme T. 1998. Parlers du Gabon: classification du 11.12.97. Raponda-Walker, A. (Ed.). 1998. Les langues du Gabon. Libreville: Éditions Raponda Walker.

Mabika Mbokou, Ludwine. Forthcoming. The Dictionnaire français-yipounou/yipounou-français of the Église Évangélique du Sud Gabon (CMA) 1966. Lexikos 16.

Matthews, P.H. 1997. The Concise Oxford Dictionary of Linguistics. Oxford/New York: Oxford University Press.

Mavoungou, Paul A. 2001a. La mondialisation et la lexicographie trilingue ou plurilingue au Gabon. J.D. Emejulu (Ed.). 2001: 160-183.

Mavoungou, Paul A. 2001b. Macro- and Microstructural Issues in Mazuna Lexicography. Lexikos 11: 122-138.

Mavoungou, Paul A. 2002a. Metalexicographical Criteria for the Compilation of a Trilingual Dictionary: Yilumbu-English-French. Unpublished D.Litt. Dissertation. Stellenbosch: University of Stellenbosch.

Mavoungou, Paul A. 2002b. Vers un dictionnaire du français du Gabon. Emejulu, J.D. (Ed.). 2002: 230-262.

Mavoungou, Paul A. 2004. Review of L.J. van der Veen and S. Bodinga-bwa-Bodinga: Gedandi sa Geviya/Dictionnaire Geviya-Français. Lexikos 14: 440-448.

Mba-Nkoghe, Jules. 1991. Le Gabon linguistique. Notre Librairie 105: 20-23.

Mihindou, Guy-Roger. 2001. Apports des missionnaires à la lexicographie gabonaise: dictionnaires bilingues fang-français/français-fang; français-yipounou/yipounou-français; français-mpongwé. Emejulu, J.D. (Ed.). 2001: 7-37.

Moulougui Nguimbyt, Franck V. 2002. De la variation dialectale en français au Gabon. Unpublished M.A. Thesis. Libreville: Omar Bongo University.

Moussirou Mouyama, Auguste. 1984. La langue française au Gabon: Contribution sociolinguistique. Thèse de Doctorat 3è cycle. Paris: Université René Descartes (Paris V).

Moussirou Mouyama, Auguste. 1986. L'introduction de la langue française au Gabon. Annales de l'Université Omar Bongo du Gabon: Série Lettres, Droit, Sciences et Médecine, 55-63.

Ndinga-Koumba-Binza, Hugues Steve. 2003. Gabonese Language Landscape (GLL). Unpublished paper presented at the 12th Biennial International Conference of the African Language Association of Southern Africa (ALASA), Stellenbosch, University of Stellenbosch, 7-11 July 2003.

Ndinga-Koumba-Binza, Hugues Steve. 2004. Le statut socio-politique du français et la promotion langues locales au Gabon. Paper presented at 18th International Conference of the Association of French Studies in Southern Africa (AFSSA), Stellenbosch, University of Stellenbosch, 8-11 September 2004.

Ndinga-Koumba-Binza, Hugues Steve. Forthcoming. Gabonese Language Landscape: Survey and Perspectives. South African Journal of African Languages 25(1).

Nyangone Assam, Blanche and Paul A. Mavoungou. 2000. Lexicography in Gabon: A Survey. Lexikos 10: 252-274. 
Nzang-Bié, Yolande. 2001. Vers une éducation multilingue au Gabon: première approche. Revue Gabonaise des Sciences du Langage/Gabonese Journal of Language Sciences 2: 17-29.

Nzang-Bié, Yolande. 2002. Le corpus lexicographique dans les langues à tradition orale: le cas du dialecte fang-mekè. Lexikos 12: 111-138.

Ogden, John. 1984. French in Gabon. Contemporary French Civilization 8: 339-348.

Pambou, Jean-Aimé. 1998. Le français au Gabon: une langue à multiples statuts. Iboogha 2: 127-149.

Perrois, L., André Jacquot and Paulette Moussavou. 1983. Situation ethnolinguistique. Géographie et cartographie du Gabon: Atlas illustré. Paris: Edicef.

Raponda-Walker, André (Ed.). 1998. Les langues du Gabon. Libreville: Éditions Raponda Walker.

Tomba Moussavou, Fatima. 2001. Les réalisations des séquences des consonnes en français de Libreville. Unpublished M.A. Thesis. Libreville: Omar Bongo University. 
Addendum 1: Gabonese Language-units according to Kwenzi-Mikala (1987, 1988, 1990 and 1998): Inventory and Internal Classification

1 MAZUNA: Fang-Atsi, Fang-Make, Fang-Mvai, FangNtumu, Fang-Nzam and Fang-Okak

2 MYENE: Enenga, Galwa, Mpongwe, Nkomi, Orungu and Adjumba

3 MEKAN-MENAA: Akele, Ungom, Lisigu, Mbangwe, Metombolo, Seki, Tumbidi, Shake, Wumpfu and Lendambomo

4 MEKONA-MANGOTE: Ikota, Benga, Shamayi, Mahongwe, Ndasa and Bakola

5 MEMBE (or OKANDE-TSOGO): Getsogo, Gepinzi, Kande, Gevove, Gehimbaka, Geviya, Ebongwe and Kota-Kota

6 MERYE: Gisira, Givarama, Givungu, Yipunu, Yilumbu, Yisangu, Ngubi, Civili, Yirimba and Yigama

7 METYE: Yinzebi, Yitsengi, Yiwele, Yivili, Liduma, Liwanzi and Yibongo

8 MEMBERE: Lembaama, Lekaningi, Lindumu, Latege and Latsitsege

9 MAKENA: Bekwil, Shiwa (or Makina) and Mwesa

10 BAKA: Baka 
Addendum 2: Foreign African Languages in Gabon

\begin{tabular}{|c|c|c|}
\hline Country of Origin & Languages & Mostly spoken in \\
\hline Angola & Ngola & Libreville \\
\hline Benin & Adja, Fon, Nago, Watchi & $\begin{array}{l}\text { Franceville, Lambaréné, } \\
\text { Libreville, Mouila, Port- } \\
\text { Gentil, Tchibanga }\end{array}$ \\
\hline Cameroon & $\begin{array}{l}\text { Aghemwun, Bafia, } \\
\text { Bamileke, Bamun, Bassa, } \\
\text { Batanga, Bete, Bulu, } \\
\text { Duala, Eton, Fingwe, } \\
\text { Hausa, Kako, Laka, } \\
\text { Meka, Sango }\end{array}$ & $\begin{array}{l}\text { Bitam, Lambaréné, } \\
\text { Libreville, Minvoul, } \\
\text { Oyem, Port-Gentil }\end{array}$ \\
\hline Congo-Brazzaville & $\begin{array}{l}\text { Kako, Kikongo, Laari, } \\
\text { Mboshi }\end{array}$ & $\begin{array}{l}\text { Franceville, Libreville, } \\
\text { Mayumba, Ndéndé, } \\
\text { Tchibanga }\end{array}$ \\
\hline $\begin{array}{l}\text { Democratic Republic of } \\
\text { the Congo }\end{array}$ & $\begin{array}{l}\text { Kisakata, Kiswahili, } \\
\text { Lingala, Pende, Tetela, } \\
\text { Zande }\end{array}$ & Libreville, Port-Gentil \\
\hline Equatorial Guinea & Bubi & Bitam, Libreville, Oyem \\
\hline Ghana & $\begin{array}{l}\text { Asante, Banda, Ewe, } \\
\text { Fingwe, Laka }\end{array}$ & Libreville, Port-Gentil \\
\hline Guinea-Conakry & Halpular, Manding & Libreville, Port-Gentil \\
\hline Ivory Coast & Baule, Ebrie, Nyagafulu & Libreville, Port-Gentil \\
\hline Mali & $\begin{array}{l}\text { Bambara, Malinke, } \\
\text { Sarakole, Sonraï }\end{array}$ & $\begin{array}{l}\text { Franceville, Lambaréné, } \\
\text { Libreville, Mouila, Port- } \\
\text { Gentil, Tchibanga }\end{array}$ \\
\hline Nigeria & $\begin{array}{l}\text { Buna, Hausa, Igbo, } \\
\text { Laka, Yoruba }\end{array}$ & Libreville, Port-Gentil \\
\hline $\begin{array}{l}\text { Republic of Central } \\
\text { Africa }\end{array}$ & $\begin{array}{l}\text { Banda, Kako, Laka, } \\
\text { Ngola, Sango }\end{array}$ & Libreville \\
\hline Rwanda & Kinyarwanda & Libreville, Franceville \\
\hline São Tomé and Príncipe & Creole & Libreville, Port-Gentil \\
\hline Senegal & $\begin{array}{l}\text { Halpular, Manding, } \\
\text { Sossamahi, Wolof }\end{array}$ & $\begin{array}{l}\text { Franceville, Lambaréné, } \\
\text { Libreville, Mouila, Port- } \\
\text { Gentil, Tchibanga }\end{array}$ \\
\hline Togo & $\begin{array}{l}\text { Fon, Kotokoli, Mina, } \\
\text { Watchi }\end{array}$ & $\begin{array}{l}\text { Libreville, Lambaréné, } \\
\text { Port-Gentil }\end{array}$ \\
\hline
\end{tabular}


Addendum 3: $\quad$ European Languages in Gabon

\begin{tabular}{|l|l|l|}
\hline Country of Origin & Languages & Mostly spoken in \\
\hline Argentina & Spanish & Libreville \\
\hline Brazil & Portuguese & Libreville \\
\hline Canada & English, French & Libreville \\
\hline Equatorial Guinea & Spanish & Libreville, Oyem, Bitam \\
\hline France & French & $\begin{array}{l}\text { Libreville, Franceville, } \\
\text { Port-Gentil }\end{array}$ \\
\hline Ghana & English & Libreville, Port-Gentil \\
\hline Germany & German & Libreville, Port-Gentil \\
\hline Italy & Italian & Libreville \\
\hline Netherlands & Dutch & Gamba, Port-Gentil \\
\hline Nigeria & English & Libreville, Port-Gentil \\
\hline $\begin{array}{l}\text { São Tomé and Príncipe, } \\
\text { Cape Verde, Angola }\end{array}$ & Portuguese & Libreville \\
\hline
\end{tabular}

Addendum 4: Middle Eastern and Asian Languages in Gabon

\begin{tabular}{|l|l|l|}
\hline Country of Origin & Languages & Mostly spoken in \\
\hline China & Chinese & Libreville, Omboué \\
\hline Japan & Japanese & Libreville \\
\hline Lebanon & Arabic & $\begin{array}{l}\text { Libreville, Port-Gentil, } \\
\text { Franceville }\end{array}$ \\
\hline Malaysia & Malaysian & $\begin{array}{l}\text { Mayumba, Ndindi, } \\
\text { Tchibanga, Lambaréné }\end{array}$ \\
\hline Mauritania & Arabic & $\begin{array}{l}\text { Libreville, Port-Gentil, } \\
\text { Franceville, Lambaréné, } \\
\text { Mouila, Oyem }\end{array}$ \\
\hline Morocco & Arabic & Libreville, Port-Gentil \\
\hline
\end{tabular}

